\title{
The Impact of Extensive Grazing on the Fertility of Mountain Streams on the Example of the Biała Woda Valley in the Pieniny Range (Polish Carpathians)
}

\author{
Andrzej Jaguś 1 \\ 1 University of Bielsko-Biala, Willowa 2, 43-309 Bielsko-Biała, Poland \\ e-mail: ajagus@ath.bielsko.pl
}

\begin{abstract}
The content of biogenic substances, i.e. ammonia $\left(\mathrm{NH}_{4}^{+}\right)$, nitrates $\left(\mathrm{NO}_{3}^{-}\right)$and phosphates $\left(\mathrm{PO}_{4}^{3-}\right)$, in the mountain stream waters was studied. The test (zero) sample was the water flowing from forest areas, while the study samples included the water from the streams flowing through extensively used sheep pastures. The impact of grazing on the water quality during high (in the rainy season) and low (in the dry period) water flows was assessed. The studies demonstrated the water contamination with ammonia, particularly during the rainy season. The contamination was also present in the test sample, so it cannot be attributed to the grazing activity. The highest nitrate concentrations were reported in the dry period. An influence of grazing on the migration of nitrates into waters was found, however, on a scale causing no contamination. The water contamination with phosphates was found. The studies demonstrated that extensive grazing did not affect the fertilisation of mountain stream water, yet the water quality may be deteriorated by the surface runoff processes and soil cover erosion.
\end{abstract}

Keywords: mountain areas, extensive agriculture, sheep pasture, biogenic substances, water contamination

\section{INTRODUCTION}

The sources of chemical substances in surface waters are very diverse; however, the occurrence of biogenic substances (nutrients) is largely associated with the agricultural activities (Sapek 1998). The biogens from agricultural areas penetrate into watercourses and reservoirs along with the surface and underground runoff. In the former case, their migration is a result of a broadly understood erosion of the earth surface, whereas in the latter case, water seepage through the soil-rock cover and leaching of the substance in dissolved form. It is estimated that in Poland, $45 \%$ of nitrogen and $20 \%$ of the phosphorus load carried by rivers comes from agriculture (Sapek and Sapek 2005). The problem of the agricultural pollution is a consequence of incorrect balancing of nutrients in agronomy (i.e. improper fertiliser management) and a result of dispersing the elements unused in plant and animal production into the environment. Numerous studies (Strauch et al. 2009, Jagus and Rzetala 2012, Burt et al. 2013, Szczykowska et al. 2015, Melland et al. 2018) prove that in catchments with agricultural activity, the water in rivers and reservoirs is often characterised by high fertility, i.e. excessive concentration of biogenic substances, which may result in eutrophication.

The aquatic environment in agricultural land should be monitored to protect the water resources. This is particularly true for the mountain areas which are considered to be ones providing a significant percentage of water on a supra-regional scale. In the Polish Carpathians, covering 6.3\% of the Poland's area, $13 \%$ of the country's water resources are created (Starkel 1990). It is not only the quantity but alto the quality of water that is important. Good quality ensures a favourable hydrobiological condition of the flowing and stagnant water ecosystems, and also contributes to reducing the cost of water supply to the residents of piedmont areas. 
The study was aimed at assessing the threat to the water quality from the areas used as pastures. In literature, the problem is mainly analysed for intensive pastures where, apart from the droppings of animals being grazed, additional fertilisation is used (Nash et al. 2019, Pilon et al. 2019). The migration of biogens from such pastures translates generally into the quality of the aquatic environment. This article describes the studies on unfertilised mountain pastures used for sheep grazing. Such pastures are considered as a part of the so-called extensive agriculture (Nastic et al. 2017, Lasanta et al. 2019), typical mainly for the areas with adverse environmental conditions (shallow and barren soils, inclement weather etc.).

\section{RESEARCH AREA}

The research was carried out in the Polish Carpathians, between the Pieniny and Beskid Sądecki mountain ranges. It is a region of various research projects completed by the author of this article over the past twenty years. The Biała Woda stream catchment area (Figure 1) located in the vicinity of Jaworki, popular tourist destination, was chosen to study the problem in question.
The catchment has the following physiographic parameters (Kurek 1977):

- area $10.91 \mathrm{~km}^{2}$;

- average width of $2 \mathrm{~km}$;

- average elevation $842.1 \mathrm{~m}$ above sea level;

- average slope gradient of $24 \%$;

- dominant exposure of the SW slopes;

- average annual precipitation of $904 \mathrm{~mm}$.

Afforestation of the catchment till the 1980s was very low and amounted to $21 \%$ (Kurek 1977). It resulted from the historical conditions. Until the end of the World War II, the area around today's Jaworki was inhabited by Ruthenians and used predominantly as arable land and pastures for cattle and sheep. After the War, the Ruthenians were displaced, and the abandoned lands were used as pastures for the sheep brought here for the grazing season from the surrounding regions. Around 30-40 thousand sheep were herded in the vicinity of Jaworki. Since the 1980 s, the sheep population began to decline due to an increase in the breeding cost with the economic support being simultaneously withdrawn. Currently, around 4,000 sheep are herded, about 1,500 of which in the Biała Woda valley. The afforestation of the catchment area has increased significantly, and now amounts to $60 \%$. It is hence a forest and

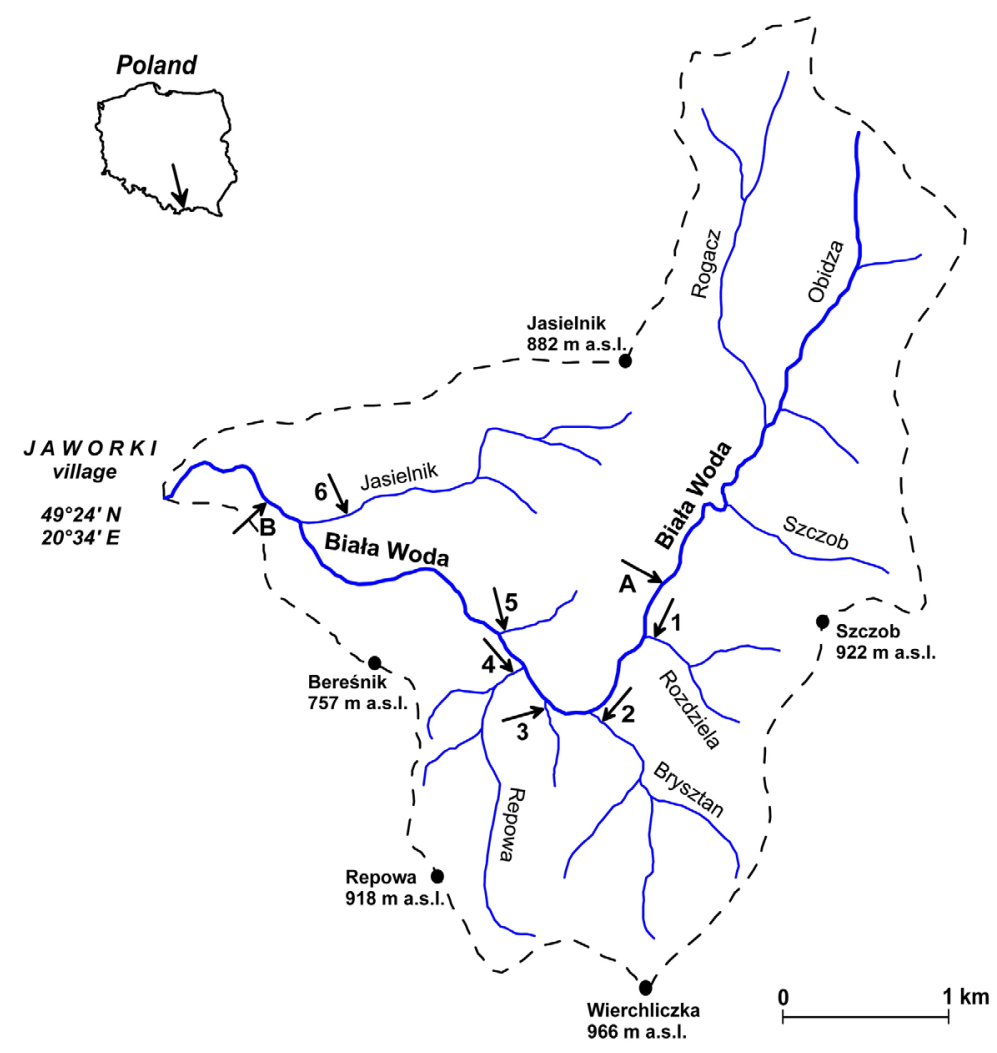

Figure 1. The Biała Woda stream catchment and the location of the water quality testing points 
agricultural catchment where the agricultural activity involves extensive grazing (Figure 2). Each year, the sheep grazing period lasts from the first days of May to the first days of October. It is worth adding that the extensive grazing of sheep in the Biała Woda valley, apart from its significance for the cultural tradition of the region, plays important environmental functions. First of all, it prevents the unwanted self-afforestation of the grass ecosystems.

The pasture areas extend in the middle and lower parts of the catchment, from the Rozdziela stream down the catchment, with partial catchment areas used for grazing being also partly forested. The grazing is guarded, but there are no fenced sections in the pastures. Flocks of sheep are led by shepherds with dogs in such a manner that the vegetation is consumed in subsequent parts of the pasture and that it can gradually regrow. The pastures are not treated with additional fertilisers except for the grazed sheep droppings. The droppings are produced both during grazing at day time and while being kept in the fenced piece of pasture at night. The first form of fertilisation is hence dispersed. The second involves fertilisation focusing on a small area. At night, the sheep are kept in a portable barnyard. There is between 1 and $3 \mathrm{~m}^{2}$ area available per one sheep. At a density of 1 sheep per $1 \mathrm{~m}^{2}, 240 \mathrm{~kg} / \mathrm{ha}$ of nitrogen and $20 \mathrm{~kg} / \mathrm{ha}$ of phosphorus are excreted into the soil with droppings per day (Twardy and Hamnett 2000). The barnyard has to be moved to a different place every day. With lower animal density, it is moved every 2 or 3 days.

In the pasture areas of the catchment in question, there are mainly sandy loam soils (in the higher parts of the land) and sandy clay loam soils (in the lower parts of the land). They are characterised by high water retention capacity. Due to the covering of soils with permanent turf vegetation and formation of a lumpy structure (the effect of the roots of grass species), the surface runoff phenomena are limited here (Kostuch and Kopeć 1980). Only in the middle of the main valley and near-stream areas of the lowest parts of the terrain, there are loam clay deposits, which impede the rainwater infiltration and are subject to erosion. The surface runoffs are therefore observed, but this does not apply to the pastures located higher. In the higher parts of the area, the rainwater flows primarily through the farm roads.

\section{METHODS}

Six small streams flowing through the grazing land and into the Biała Woda stream were chosen for testing the water quality. The study also included the Biała Woda stream above the grazing areas (in the forested part of its catchment) and after receiving the waters of all the examined tributaries. The water samples for laboratory analyses were taken in two series, during high and low water flows. The first series was completed on June 4, 2019 after a period of heavy rainfall, and the second on August 20, 2019 during a long rainless period. The locations of the water intake points are shown in Figure 1. The points were numbered as follows:

A - Biała Woda stream (Figure 3) - zero test sample;

1 - Rozdziela stream;

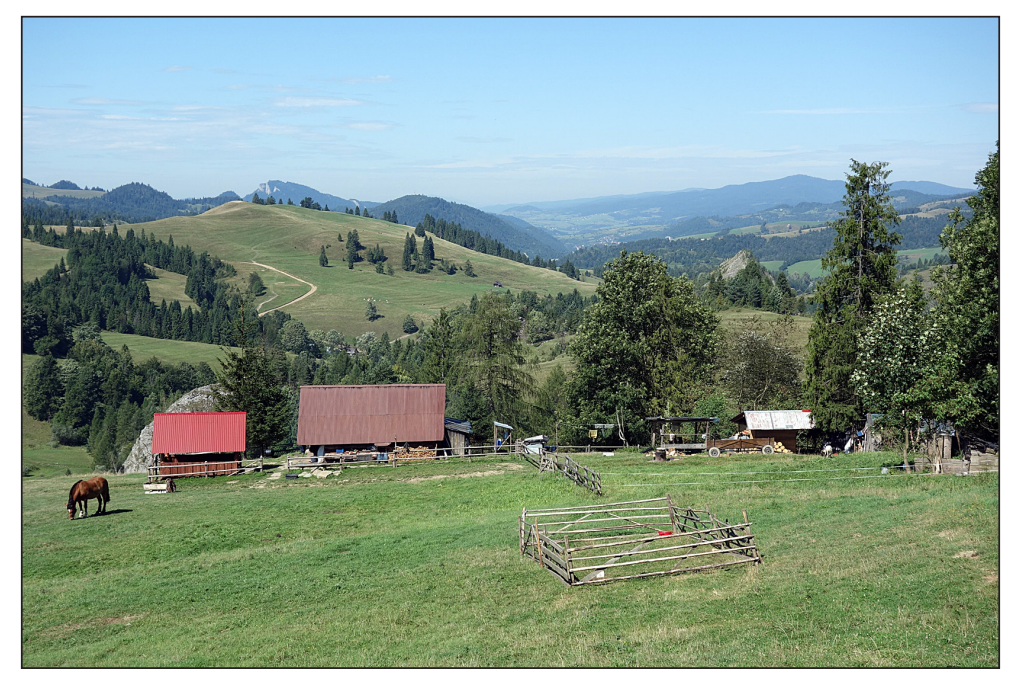

Figure 2. Pasture areas in the Biała Woda valley with buildings of one of the herding farms (photo by A. Jaguś) 


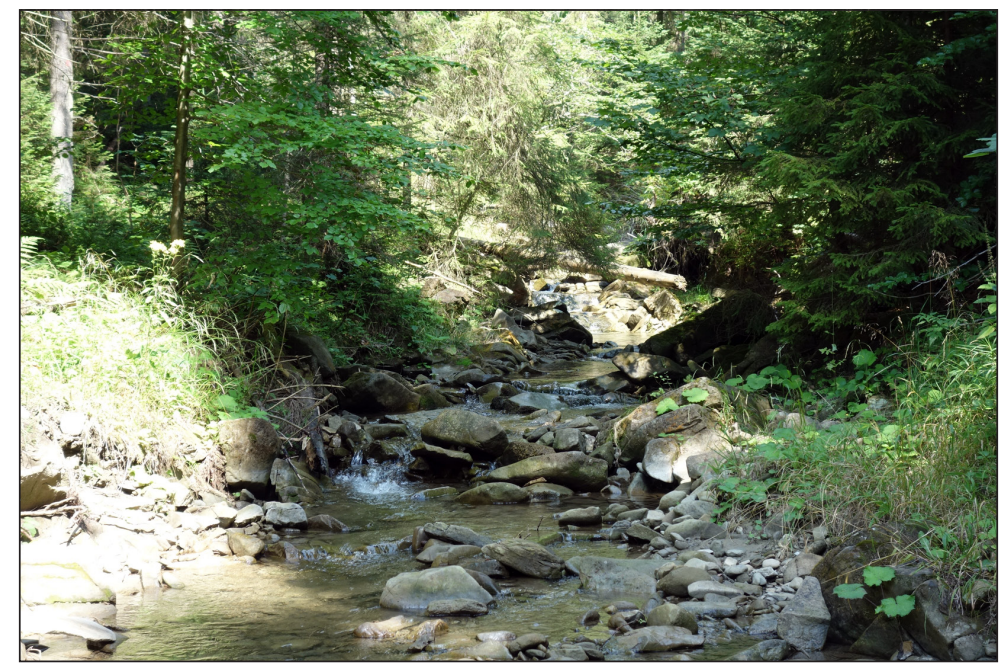

Figure 3. The Biała Woda stream flowing out of the forested part of the catchment (photo by A. Jaguś)

2 - Brysztan stream (Figure 4);

3 - an unnamed stream above Repowa;

4 - Repowa stream;

5 - an unnamed stream at a waterfall;

6 - Jasielnik stream;

B - Biała Woda stream - final sample.

The collected water was analysed for the content of biogenic substances, i.e. ammonia $\left(\mathrm{NH}_{4}^{+}\right)$, nitrates $\left(\mathrm{NO}_{3}^{-}\right)$and phosphates $\left(\mathrm{PO}_{4}^{3-}\right)$. The analyses were carried out immediately after sampling with a portable photometer. The assays consisted in determining the intensity of water colour after the application of appropriate reagents in relation to raw water.

In the first assay, the ammonium ions present in water, in a diluted sodium hydroxide medium, react with an organic chlorinating complex.
Monochloramine is formed, which - in reaction with thymol - produces the indophenol blue.

In the second assay, nitrates are reduced to nitrites in the presence of a zinc catalyst. Then, the nitrites form a diazonium salt with amines which, by conjugation with the aromatic amine, transforms into the purple-red azo dye.

The third assay is referred to as the molybdate method. The orthophosphates assayed in combination with ammonium heptomolybdate form the phosphoric-molybdate acid which is reduced to phosphorous-molybdate blue.

\section{RESULTS AND DISCUSSION}

At the beginning of the study, it was assumed that the content of the nitrogen and phosphorus compounds in the water of the Biała Woda stream

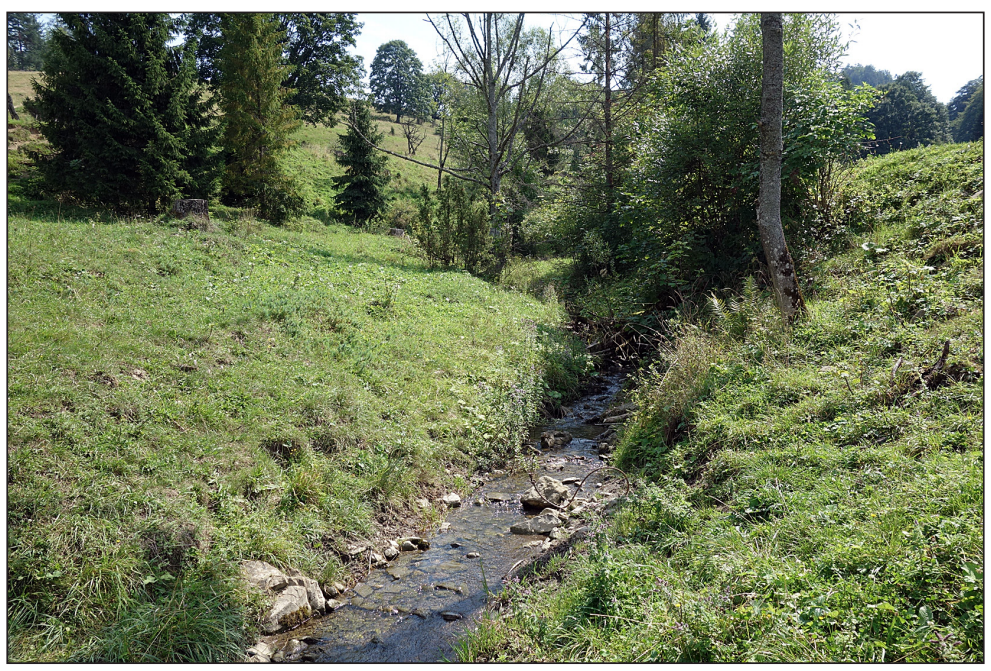

Figure 4. The Brysztan stream flowing out of grazing land (photo by A. Jaguś) 
flowing from the forest areas would be noticeably lower than in the waters of other streams. Among others, the appearance of the stream bed at the sampling point was considered. In the case of the Biała Woda stream (zero sample), it was clean, while those of the streams flowing through the grazing areas were covered with a thin layer of silt (the presence of silt can be associated with passing of sheep flocks through streams and digging into stream beds with hooves). That basic assumption, however, turned out to be true only for nitrates. The ammonia and phosphate concentrations in the zero sample were similar to those in other samples. Therefore, the water of the Biała Woda stream, after receiving the water from the grazing areas, i.e. in the final sample, was enriched only with nitrates.

The study showed a slight variation in the ammonia and nitrate concentrations in the waters of individual streams, with more distinct differences between the samples from the rainy and dry periods. For phosphates, the concentration values were very close in most samples (Table 1).

Ammonia $\left(\mathbf{N H}_{4}^{+}\right)$was present in higher concentrations during the rainy period, $0.90 \mathrm{mg} / \mathrm{dm}^{3}$ on average. This is due to the presence of that compound in the surface runoff waters. Firstly, it is an important component of rainwater and, secondly, it is leached from the surface layer of soil containing organic matter, including animal droppings. In the dry period, the ammonia concentrations were clearly lower, $0.36 \mathrm{mg} / \mathrm{dm}^{3}$ on average, because during deep infiltration (underground seepage) this compound undergoes biochemical changes. This is best confirmed by the results of the lysimeter studies continued for several decades in Jaworki. Researchers (e.g. Kopeć 1990) generally found low levels of ammonia (several or dozen hundredths of $\mathrm{mg} / \mathrm{dm}^{3}$ ) in the waters infiltrating through the soil profile, both in the absence of fertilisation and with the use of different doses of fertilisers. Therefore, the ammonia present in the waters of the studied streams, during the dry period, comes partly from the washing of the bed zones which are, as already mentioned, penetrated by the sheep. For the water from the forest areas (zero sample), the origin of ammonia can be attributed to the washing of dead organic matter accumulated in the bed of the stream.

The ammonia concentrations recorded during the study indicated that the streams were contaminated with that compound. The concentrations in all cases exceeded the level of $0.1 \mathrm{mg} \mathrm{N}-\mathrm{NH}_{4} / \mathrm{dm}^{3}$ i.e. $0.13 \mathrm{mg} \mathrm{NH}{ }_{4}^{+} / \mathrm{dm}^{3}$, provided by the Polish legislation for the best water quality class (class I out of five) in the streams in the mountain areas (designation of streams in the classification of surface waters: RWf). Except for two tests, they also exceeded the limit value for quality class II, $0.2 \mathrm{mg} \mathrm{N}-\mathrm{NH}_{4} / \mathrm{dm}^{3}$ i.e. $0.26 \mathrm{mg} \mathrm{NH}_{4}^{+} / \mathrm{dm}^{3}$ (Ordinance... 2019). Another indicator of the water contamination with ammonia is a high percentage of the ammoniacal nitrogen in relation to the nitrate nitrogen. In pure water, the nitrate form definitely dominates, while in the water of the streams studied, the ammonium form represented on average as much as $65 \%$ of total nitrogen in the rainy period and $31 \%$ for the dry period.

Nitrates $\left(\mathrm{NO}_{3}{ }^{-}\right)$were present in the tested waters in concentrations from 0.8 to $5.7 \mathrm{mg} / \mathrm{dm}^{3}$. As opposed to ammonia, higher concentrations were reported during the dry period (an average of $2.7 \mathrm{mg} / \mathrm{dm}^{3}$ ) in comparison with the rainy period $\left(1.7 \mathrm{mg} / \mathrm{dm}^{3}\right.$ on average). This is due to the fact that nitrates, which are formed in the soil environment during the nitrification process, migrate mainly underground together with the seepage

Table 1. Biogen concentrations in the surface waters in the Biała Woda catchment (location of test points according to Figure 1) in the rainy and dry period

\begin{tabular}{|c|c|c|c|c|c|c|}
\hline \multirow[t]{2}{*}{ Sampling point } & \multicolumn{2}{|c|}{$\begin{array}{c}\mathrm{NH}_{4}^{+} \\
{\left[\mathrm{mg} / \mathrm{dm}^{3}\right]}\end{array}$} & \multicolumn{2}{|c|}{$\begin{array}{c}\mathrm{NO}_{3}^{-} \\
{\left[\mathrm{mg} / \mathrm{dm}^{3}\right]}\end{array}$} & \multicolumn{2}{|c|}{$\begin{array}{c}\mathrm{PO}_{4}^{3-} \\
{\left[\mathrm{mg} / \mathrm{dm}^{3}\right]}\end{array}$} \\
\hline & Rainy & Dry & Rainy & Dry & Rainy & Dry \\
\hline A - Biała Woda & 1.02 & 0.48 & 0.8 & 1.0 & 0.06 & 0.05 \\
\hline 1 - Rozdziela & 0.85 & 0.37 & 2.2 & 2.7 & 0.05 & 0.06 \\
\hline 2 - Brysztan & 0.92 & 0.36 & 1.6 & 2.9 & 0.06 & 0.06 \\
\hline 3 - stream above Repowa & 0.81 & 0.14 & 2.7 & 5.7 & 0.05 & 0.06 \\
\hline 4-Repowa & 1.03 & 0.61 & 1.1 & 2.9 & 0.05 & 0.04 \\
\hline $5-$ stream at a waterfall & 0.74 & 0.40 & 1.5 & 1.8 & 0.04 & 0.05 \\
\hline 6 - Jasielnik & 0.90 & 0.39 & 2.2 & 3.0 & 0.09 & 0.07 \\
\hline B - Biała Woda & 0.96 & 0.16 & 1.5 & 1.5 & 0.06 & 0.06 \\
\hline
\end{tabular}


water (in the dry periods, the underground water continues flowing in streams). The highest nitrate concentration occurred in the dry period, in sample 3 - it is a stream with the lowest water content of all streams studied (a small amount of water in the watercourse is usually associated with a high concentration of chemical substances dissolved in water).

The nitrates were found to infiltrate into water in the pasture areas in a greater amount than in the forest areas. The concentrations in the zero sample were half or third of the values in the other samples. It is a consequence of a greater nitrogen content in the soils of pasture areas compared to the forest soil (Jaguś and Skrzypiec 2017) - the coniferous stand in the Biała Woda catchment does not provide enough organic matter to enrich the soil with nitrogen, as it is the case of the deciduous stand (Rahmonov et al. 2011, Jaguś and Skrzypiec 2017). However, it should be noted that the concentration values in all samples, both from forest and pasture areas, can be considered low. The Polish legislation (Ordinance... 2019) provides the maximum concentration of $0.8 \mathrm{mg} \mathrm{N}-\mathrm{NO}_{3} / \mathrm{dm}^{3}$ for waters of quality class I, i.e. $3.54 \mathrm{mg} \mathrm{NO}_{3}^{-} / \mathrm{dm}^{3}$, which was exceeded only once in the sample 3 mentioned. The maximum concentration for class II waters was $1.3 \mathrm{mg} \mathrm{N}-\mathrm{NO}_{3} / \mathrm{dm}^{3}$, i.e. $5.75 \mathrm{mg} \mathrm{NO}{ }_{3}^{-} / \mathrm{dm}^{3}$, so it had not been exceeded.

The agricultural activity usually causes the contamination of the aquatic environment with nitrates; therefore, the results obtained in the pasture areas studied are optimistic in the context of the water resources protection. Since nitrates are not retained by the soil sorption complex, absorption by vegetation has to be the factor limiting their migration. Numerous studies on the leaching of nitrates from various agricultural crops indicate (e.g. Smoroń et al. 1996, Hussain et al. 2019) that the protective function for waters is best performed by the perennial grassy vegetation. Such kind of vegetation effectively absorbs nitrates even under the application of high doses of fertilisers (Jagła and Misztal 2000).

Phosphates $\left(\mathrm{PO}_{4}{ }^{3-}\right)$ occurred in the waters tested in the amount of several hundredths of $\mathrm{mg} / \mathrm{dm}^{3}$. The concentrations were almost identical during the rainy and dry periods. There were also no differences between the water flowing out of the forest and pasture areas. Those findings indicate high stability of this substance in the soil environment. In the lysimeter studies conducted in Jaworki, it was repeatedly demonstrated (e.g. Kopeć 1985) that even the use of phosphorus fertilisation does not cause a marked increase in the phosphate concentrations in the waters leaching from soil profiles. This is due to the formation of poorly soluble phosphorus compounds in the soil, e.g. $\mathrm{Ca}_{3}\left(\mathrm{PO}_{4}\right)_{2}, \mathrm{FePO}_{4}, \mathrm{AlPO}_{4}$ and the sorption of phosphate ions by soil colloids. Only small amounts of phosphate ions originating from orthophosphoric acid or soluble phosphates, e.g. $\mathrm{Ca}\left(\mathrm{H}_{2} \mathrm{PO}_{4}\right)_{2}$ migrate in a dissolved form.

It is well known that the movement of phosphorus into the surface waters occurs along with surface runoff carrying soil particles. Numerous researchers (e.g. Monaghan et al. 2016) reported that this is the main migration route for this element in agricultural areas. As already mentioned, the surface runoff in the Biała Woda catchment area does not apply to the grazing areas, but mainly to the near-stream areas and farm roads. The water runoff is most visible in the Jasielnik stream catchment, where the forestry works are carried out using heavy machinery. This may explain a slightly higher concentration of phosphates in the water of that stream compared to other streams. However, a greater amount of phosphates is probably the cause of the development of bryophytes and benthic algae in the Jasielnik stream bed (Figure 5). In other streams, those organisms are not visible or they occur in much smaller amounts.

The phosphate concentrations recorded in the tests (with the exception of concentrations in the Jasielnik stream) were within the limits specified for water quality class I, i.e. they did not exceed $0.02 \mathrm{mg} \mathrm{P}-\mathrm{PO}_{4} / \mathrm{dm}^{3}$, i.e. $0.06 \mathrm{mg}$ $\mathrm{PO}_{4}^{3-} / \mathrm{dm}^{3}$ (Ordinance... 2019). In the water of the Jasielnik stream, the level of class I was slightly exceeded (the range of concentrations for quality class II is from 0.07 to $0.18 \mathrm{mg} \mathrm{PO}_{4} / \mathrm{dm}^{3}$ ). Therefore, the waters examined cannot be considered as contaminated with phosphates which are assumed the main substance determining the fertility of the environment.

\section{CONCLUSION}

The surface waters in the Biała Woda stream catchment show contamination with ammonia, particularly during the rainy periods. The threat to the water quality results mainly from the surface runoff phenomena and does not have to be associated with the grazing activity. In the dry periods, 


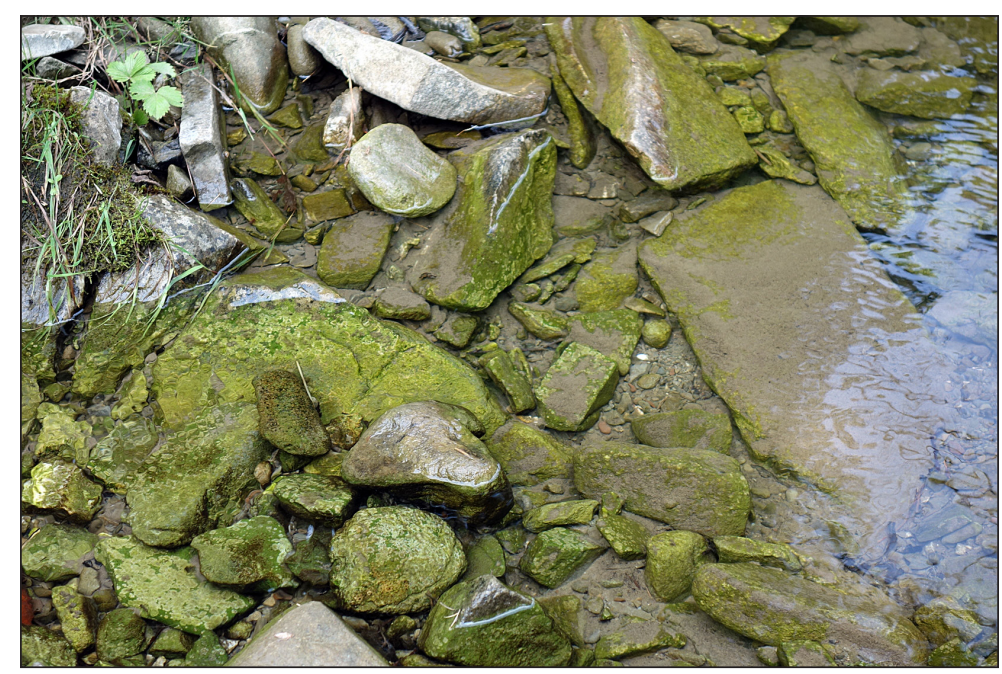

Figure 5. Phytobenthos in the Jasielnik stream bed (photo by A. Jaguś)

the ammonia concentrations are also excessive, prompting the search for its sources in the bed and near bed areas of the streams.

Pastures are the source of nitrates in the surface waters to a greater extent than the forest areas. This is particularly apparent in the dry periods, i.e. periods of underground supply to watercourses, and is related to the nitrogen content of soil. However, the nitrate contents are low which means that the grazing has its effects but it does not cause contamination of the waters.

The threat of water pollution by phosphates should be associated mainly with the processes of the soil cover erosion. The pasture land is not a significant source of phosphates in stream waters.

Extensive grazing does not contribute to the fertilisation of mountain streams in the Biała Woda catchment. In order to maintain a favourable situation, it appears necessary only to minimise the human interference in the bed and nearbed areas of the streams and to reduce the works violating the structure of soil covers.

\section{REFERENCES}

1. Burt C., Bachoon D.S., Manoylov K., Smith M. 2013. The impact of cattle farming best management practices on surface water nutrient concentrations, faecal bacteria and algal dominance in the Lake Oconee watershed. Water and Environment Journal, 27(2), 207-215.

2. Hussain M.Z., Bhardwaj A.K., Basso B., Robertson G.P., Hamilton S.K. 2019. Nitrate leaching from continuous corn, perennial grasses, and poplar in the US Midwest. Journal of Environmental Quality, 48(6), 1849-1855.
3. Jagła S., Misztal A. 2000. The effect of vegetation cover on the water environment of differently used soil under mountain condition (based on the lysimeter studies). Problemy Zagospodarowania Ziem Górskich, 46, 35-46 (in Polish).

4. Jagus A., Rzetala M. 2012. Hydrochemical consequences of feeding flow-through reservoirs with contaminated water. Rocznik Ochrona Srodowiska, 14, 632-649 (in Polish).

5. Jagus A., Skrzypiec M. 2017. The soil-spatial conditions of agricultural activity in the area of Beskid Mts. Acta Scientiarum Polonorum Formatio Circumiectus, 16(2), 97-106 (in Polish).

6. Kopeć S. 1985. The amount of losses of basic fertilizer components runoff with lysimeter water in mountain conditions. Wiadomości Instytutu Melioracji i Użytków Zielonych, 15(2), 247-264 (in Polish).

7. Kopeć S. 1990.Assessment of migration of fertilizer components to groundwater based on lysimeter studies.Materiały seminaryjne IMUZ, 27, 163-175 (in Polish).

8. Kostuch R., Kopeć S. 1980. Importance of permanent grassland in the water economy of mountains. Zeszyty Problemowe Postępów Nauk Rolniczych, 235, 165-175 (in Polish).

9. Kurek S. 1977. Maximum outflows from small mountain catchments with varying degrees of afforestation (exemplified by the upper Grajcarek river basin). Gospodarka Wodna, 4, 98-101 (in Polish).

10. Lasanta T., Nadal-Romero E., Garcia-Ruiz J.M. 2019. Clearing shrubland as a strategy to encourage extensive livestock farming in the mediterranean mountains. Cuadernos de Investigacion Geografica, 45(2), 487-513.

11. Melland A.R., Fenton O., Jordan P. 2018. Effects of agricultural land management changes on surface 
water quality: A review of meso-scale catchment research. Environmental Science \& Policy, 84, 19-25.

12. Monaghan R.M., Smith L.C., Muirhead R.W. 2016. Pathways of contaminant transfers to water from an artificially-drained soil under intensive grazing by dairy cows. Agriculture Ecosystems\& Environment, 220, 76-88.

13. Nash D.M., McDowell R.W., Condron L.M., McLauglin M.J. 2019. Direct exports of phosphorus from fertilizers applied to grazed pastures. Journal of Environmental Quality, 48(5), 1380-1396.

14. Nastic L., Markovic T., Ivanowic S. 2017. Economic efficiency of extensive livestock production in the European Union. Ekonomika PoljoprivredaEconomics of Agriculture, 64(3), 1219-1230.

15. Ordinance of the Polish Minister of Maritime Economy and Inland Navigation of 11 October 2019 on the classification of ecological status, ecological potential and chemical status and the method of classifying the status of surface waters as well as environmental quality standards for priority substances. DzU 2019, poz. 2149 (in Polish).

16. Pilon C., Moore P.A. Jr., Pote D.H., Martin J.W., Owens P.R., Ashworth A.J., Miller D.M., DeLaune P.B. 2019. Grazing management and buffer strip impact on nitrogen runoff from pastures fertilized with poultry litter. Journal of Environmental Quality, 48(2), 297-304.

17. Rahmonov O., Rzetala M.A., Rahmonov M., Kozyreva E., Jagus A., Rzetala M., 2011: The formation of soil chemistry and the development of fertility islands under plant canopies in sandy areas. Research Journal of Chemistry and Environment, 15(2), 823-829.

18. Sapek B. 1998. Farm as a source of soil, water and air pollution with nitrogen, phosphorus and potassium. Bibliotheca Fragmenta Agronomica, 3, 124-144.

19. Sapek A., Sapek B. 2005. Strategy of nitrogen and phosphorus management in agriculture for the protection of waters of the Baltic Sea. Zeszyty Edukacyjne IMUZ, 10, 27-38 (in Polish).

20. Smoroń S., Kopeć S., Misztal A. 1996. The dynamics of nitrates in infiltrating waters accompanying different agricultural crops.Zeszyty Problemowe Postępów Nauk Rolniczych, 440, 367-374 (in Polish).

21. Starkel L. 1990. Spatial differentation of the Carpathian environment and the needs changes in land utilization. Problemy Zagospodarowania Ziem Górskich, 30, 11-29 (in Polish).

22. Strauch A.M., Kapust A.R., Jost C.C. 2009. Impact of livestock management on water quality and streambank structure in a semi-arid, African ecosystem. Journal of Arid Environments, 73(9), 795-803.

23. Szczykowska J., Siemieniuk A., Wiater J. 2015. Agricultural pollution and water quality in small retention reservoir in Korycin. Journal of Ecological Engineering, 16(1), 141-146.

24. Twardy S., Hamnett R.G. 2000. Low input grassland production systems for livestock feeding in the Polish Carpathians. Wydawnictwo IMUZ, Falenty (in Polish). 